\title{
Stable states and thresholds of range condition on North American rangelands: A viewpoint
}

\author{
W.A. LAYCOCK
}

\begin{abstract}
The concepts of relatively stable multiple states and thresholds or transitions between these states has received little attention in range management until recently. On North American rangelands lower successional stable states occur in sagebrush and other shrub-dominated vegetation types in the Great Basin, the shortgrass steppe, the Southwestern desert grasslands, and communities dominated by annual grasses in California and southern Idaho. Recognition of these stable states and models describing them are needed to develop new concepts about range condition. The model presently used assumes a single stable state (climax) and that the stages of secondary succession on improving rangelands are the reverse of the stages of retrogession. Alternative models presented include the "cup in ball" analogy, the state-and-transition model, and others. While much theoretical work needs to be done before any of these models can be incorporated into range condition standards, it is important for range managers to recognize that multiple steady states exist for many vegetation types. One assumption of the current range condition model is that a reduction in grazing pressure and an improvement in grazing management will result in range improvement. If a vegetation type is in a stable lower successional state, it normally will not respond to change in grazing or even removal of grazing. Managers must recognize this situation when it occurs so that false expectations of improvement are not fostered.
\end{abstract}

Key Words: transition, climate, succession, grazing, site potential

The concept of thresholds of environmental change between relatively stable domains or states is not new and has been discussed widely in the ecological literature (Holling 1973, May 1977, Wissel 1984). If stability is resistance to change imposed by external forces (Margalef 1969), then a system is stable if it returns to the original steady-state after being disturbed or deflected (Verhoff and Smith 1971, May 1977). An unstable state does not return to the original level after disturbance but rather crosses a "threshold" and continues to be deflected toward some new state (Hurd and Wolf 1974).

Various models of stable states from the ecological literature will be presented later. The concept of stable states or domains has not received much attention in the range management literature until recently. Friedel $(1988,1991)$ used the concept of thresholds of environmental change to help describe and explain anomalies in condition assessments of central Australia's arid rangelands and stated that "the concept of thresholds offers a useful framework for identifying important environmental changes." Friedel (1991) pointed out that once a threshold is crossed to a more degraded state, improvement cannot be attained on a practical time scale without a much greater intervention or management effort than simple grazing control. Archer (1989) discussed mechanisms to explain how grazing might cause a shift from a grassland or savanna domain across a threshold to a shrubland or woodland domain. This new domain cannot then be altered by reduction or removal of grazing, i.e., the threshold back to a grassland domain is very difficult to cross. Schlatterer (1989) discussed alternate pathways of vegetation change with each pathway represented by a

Author is professor of range management, University of Wyoming, Laramie 82071. page of a book radiating out from the book's backing. Range retrogession or succession differs for each case or "page" depending upon the kind of disturbance and its duration and intensity. "Succession may be halted. . indefinitely at some point on the successional scale."

Westoby et al. (1989) proposed that dynamics observed on rangelands be described by a "State-and-Transition" model. The "states" are recognizable and relatively stable assemblages of species occupying a site and the "transitions" between states are triggered either by natural events (e.g., weather, fire) or by management actions (e.g. grazing, destruction or introduction of plants) or a combination of the two.

Laycock (1989) used the term "suspended stages of succession" to describe plant communities that remain almost unchanged in species composition for relatively long periods of time. Allen (1988) discussed the influence of rate and pattern of succession and also that some different trajectories of succession may not allow a disturbed ecosystem to return to its original state. The reasons for suspended stages or different trajectories of succession may include dominance by a highly competitive species or life form, long generation times of the dominant species, lack of seed or seed source, specific physiological requirements that limit seedling establishment except at infrequent intervals, climatic changes, restrictions of natural fires or others.

The concepts of state, domain, basin of attraction, stability, different trajectories of succession, and suspended stages of succession are closely related. These, coupled with the concept of thresholds of change that must be crossed for a system to move from one state to another, offer promise for improved concepts, descriptions, and measurements of range condition.

The efforts to find a new conceptual framework to recognize and describe changes in range condition have resulted, at least in part, from discontent with the current concepts about range condition. Most range condition standards in the U.S. are based on what has been called an "ecological or climax" (Friedel 1988, 1991) or a "successional" (Westoby et al. 1989) model. The concepts behind this model can be traced directly to the climax and plant succession concepts of Clements (1916) and the application of these concepts to range management by Sampson (1919). The model currently used was first proposed by Dyksterhuis (1949) and was, at that time, a relevant tie between the current ecological thought and the concept of range condition.

According to Westoby et al. (1989) the range condition model currently used assumes that: (1) a given vegetation type or range site has only 1 stable state ("climax" or "potential natural community"); (2) retrogressive changes caused by improper grazing result in unstable states which can be reversed by manipulation, reduction, or elimination of grazing; and (3) the pathway of vegetation change as rangelands improve (secondary succession) is identical to but the reverse of that followed in retrogession. In this model, (1) all possible states of vegetation can be arrayed on a single near-linear continuum from heavily grazed or early-successional communities in poor condition to ungrazed, climax communities in excellent condition, and (2) all changes (degradation or improvement) occur continuously and reversibly along this continuum (Westoby et al. 
1989). Smith $(1978,1988,1989)$, Hart and Norton (1988), Wilson (1989), Laycock (1989), Westoby et al. (1989), and Friedel (1988, 1991) have discussed the inadequacy of this model and the need for new ways to describe and interpret condition of rangelands. Many new ecological ideas and concepts have been proposed, discussed, and accepted since those of Clements (1916), Sampson (1919) and Dyksterhuis (1949) were in vogue. In order to effectively manage our rangeland resources, we need to go beyond the "conventional wisdom" of these ideas that are so deeply ingrained in the range management profession.

Attempts have been made to modify the presently used model to make it more realistic. Foran et al. (1978) expanded the model for use on a grassveld type in South Africa. In this model, condition declines because of under-utilization as well as over-utilization (Hart and Norton 1988). Schlatterer (1989) presented a similar model, one-half of which represented the typical succession-based concepts. The other half "illustrated a succession to a new and different potential as a result of various disturbances and pressures on the site that break the chain and preclude succession according to what theory would suggest."

The purposes of this paper are to: (1) present examples of relatively stable states or domains of vegetation condition on North American rangelands; and (2) discuss the models and other information needed by the range science community to clarify and implement these new (to range management) concepts of states and thresholds.

Some North American rangelands, such as the grasslands of the Great Plains, apparently evolved under rather heavy grazing by native herbivores. Heavy ungulate use on other North American rangelands began only a little more than 100 years ago, after the introduction of domestic livestock, and we have a relatively good understanding of the most common stages of retrogression for many of these rangeland types. This is not necessarily true for some range types in the southwestern U.S., California, or in other parts of the world that have a much longer history of livestock grazing. In applying succession-based methods of determining range condition, it is assumed that the stages of secondary succession on improving rangelands not only are the reverse of stages of retrogression, but that these successional stages will be the same for all sites at all times for a given range type. Gleason (1926) and Egler (1954) indicated that the initial composition of vegetation in a disturbed community and the subsequent stages of dominance by various plant species are regulated by chance and conditions at the time of the disturbance. These ideas can easily be incorporated in models describing stable states and thresholds of range condition.

\section{States and Thresholds on North American Rangelands}

Friedel (1991) indicated that 2 transitions across thresholds can be readily recognized in arid and semiarid rangelands: (1) a change from grass (or herbaceous) to woody plant dominance; and (2) changes occurring when soil erosion outstrips soil formation and soil physical and chemical properties are altered irreversibly. The Soil Conservation Service provides a method to address the latter situation. A new site with a different potential can be described.

Most of the examples of thresholds from Australia presented by Friedel $(1988,1991)$ represent stable states of vegetation or vegetation/soil reached in a situation of declining range condition. Many of the examples of the recognizable stable states of range condition on North American rangelands represent conditions from which substantial improvement is difficult, i.e., thresholds are present that are difficult to cross in order to obtain range improvement. Some of these states probably represent conditions that were reached as the rangeland areas were deteriorated by heavy grazing or other factors. Others may represent stable states that were reached after some range improvement took place when grazing pressure was substantially reduced, but further change is now difficult to obtain.

\section{Sagebrush-Grass Vegetation:}

Lower successional steady states are common in the sagebrushgrass type which covers almost $\mathbf{5 0}$ million hectares in the Great Basin and surrounding areas. The original sagebrush communities probably consisted of a fairly open stand of sagebrush with a productive understory of grasses and forbs (Laycock 1978). Periodic natural fires would have temporarily reduced the amount of sagebrush in local areas. The sagebrush type apparently had not been subjected to heavy herbivore grazing pressure since the Pleistocene (Young et al. 1976). When large numbers of domestic livestock were introduced in the late 19th century, the palatable herbaceous plants were not able to withstand the grazing pressure (Young et al. 1979). Heavy grazing during the short growing season caused rapid deterioration of the understory species and sagebrush increased. Thus, a threshold was crossed into a steady state dominated by sagebrush.

Numerous examples, on the ground and in the literature, indicate that once a stand of sagebrush (especially the various subspecies of big sagebrush, Artemisia tridentata Nutt.) becomes dense with a reduced understory, the sagebrush can dominate a site for very long periods. West et al. (1984) found no significant changes in a big sagebrush type in Utah after 14 years of livestock exclusion. Robertson (1971) found that 30 years of protection from grazing on an eroded sagebrush-grass site in northern Nevada resulted in increased vegetal cover of all life forms, including the sagebrush. Sagebrush made up $68 \%$ of the total plant cover at the end compared to $64 \%$ at the beginning of the period. Sanders and Voth (1983) found no improvement over a 45-year period in 3 exclosures dominated by big sagebrush in southwestern Idaho. In southeastern Idaho, Anderson and Holte (1981) found that both big sagebrush and grasses increased dramatically when protected from grazing for 25 years, but that there were no apparent differences in trend between the plots open to grazing and those protected from grazing. The concluded that "no evidence of seral replacement, as predicted by classical succession, was found."

The dominance of sagebrush represents a stable state which resists changes in livestock grazing management to move it across the threshold, possibly toward a grass/sagebrush state. The management implications of such states and thresholds in sagebrush and other communities will be discussed below.

\section{Other Shrub-Dominated Vegetation Types in the Great Basin}

In the Great Basin area, a number of other shrub-dominated vegetation types react in a manner similar to that of the sagebrushgrass communities. In northern Utah, Rice and Westoby (1978) examined vegetation inside and outside 12 exclosures in a number of semidesert shrub communities dominated by winterfat (Ceratoides lanata [Pursh] Moq.), Nuttall saltbush (Atriplex nuttallii S. Wats.), shadscale (Atriplex confertifolia [Torr. \& Frm.] S. Wats.), big sagebrush, and black sage (Artemisia nova Nels.). The exclosures had been protected from grazing by sheep, jackrabbits (Lepus californicus), or both for 6 to 15 years. In general, the changes caused by protection from grazing did not move the communities to a different vegetation condition or stage. Annuals were abundant at the time the exclosures were built and did not decrease under protection except for the alien halogeton (Halogeton glomeratus [Bieb] C.A. Mey.). Perennial grasses did not increase in the exclosures, either in cover, density, or number of seedlings. Winterfat increased in vigor but not in density under protection. One conclusion was that the concept of grazing succession in these semiarid shrublands is not meaningful.

Turner (1971) found that exclusion of livestock grazing for 10 years had little effect on shrub communities dominated by big 
sagebrush, shadscale, and Nuttall saltbush in western Colorado. Inherently low site capability and subnormal precipitation during the study were believed to be responsible for the lack of response of the vegetation to exclusion of grazing. However, it seems possible that the lack of response is because the vegetation was in a stable state. Some force or energy, in addition to or instead of lack of grazing, might be necessary to move the vegetation past the threshold which prevents change.

On a salt desert shrub rangeland in Utah, vegetation changes over a 40-year period were the same under heavy sheep grazing and protection from grazing (Norton 1978). Shadscale, the least palatable shrub, exhibited a short-term rise in cover followed by a steady decline. The more palatable winterfat consistently increased in cover. One conclusion from the study was that, contrary to accepted range management theory, the vegetation changes in dominant palatable and unpalatable species were not a function of grazing pressure. Sharp et al. (1990) documented cyclic changes in a shadscale community in Idaho over 40 years. These changes occurred in all areas and were caused by weather insect infestations and other factors not related to grazing.

\section{Shortgrass Steppe Vegetation:}

On shortgrass steppe areas in the Central Great Plains, blue grama (Bouteloua gracilis [HBK] Lab.) is the major species. With continued heavy grazing, many of the species associated with blue grama, especially the cool-season grasses, tend to decrease and blue grama increases in composition by weight and cover. Once this state dominated by blue grama is reached, it takes extremely heavy or abusive grazing over a period of years, heavy grazing combined with a prolonged drought (Costello and Turner 1944), or some more drastic disturbance such as plowing to remove the blue grama or make any substantial changes in the species composition. In the drier portions of the shortgrass steppe, this state dominated by blue grama appears to be quitc resistant to change caused either by heavier grazing, decreased, or removal of grazing.

A second stable state occurs on shortgrass steppe areas that have been cultivated but then allowed to revegetate naturally through secondary succession. At least some abandoned fields pass through fairly well described stages of early succession (Costello 1944) but, in some areas with less than approximately $38 \mathrm{~cm}$ of precipitation, succession may stop a with a community that includes most of the native species but without any blue grama. Some fields abandoned in the 1930s or earlier in northeastern Colorado (Wilson and Briske 1979), southeastern Wyoming (Samuel 1985, Samuel and Hart 1990), and other areas on the drier part of the Central Plains still have little or no blue grama. An area in New Mexico, farmed by Indians and abandoned approximately 800 years ago, still has no blue grama even though it is the dominant species on surrounding areas (Sandor 1983). One of the reasons for the long delay in the return of blue grama to the community may be that blue grama reproduces primarily by vegetative means (tillering) and rather restrictive moisture and temperature conditions are needed for germination and adventitious root development of blue grama seedlings (Wilson and Briske 1979). Blue grama does return on many areas (Coffin et al. 1991) and the reasons for either the return or lack of return of blue grama are not known. Where it occurs, the community without blue grama is quite stable and resistant to change.

\section{Southwestern Desert Grasslands:}

It has long been recognized that shrubby invaders of desert grasslands are slow to relinquish dominance once they become established because of fire suppression, heavy grazing or other factors (Ellison 1960). According to Paulsen and Ares (1962), creosote bush (Larrea tridentata [DC] Coville) and tarbush (Flourensia cernua DC) are the primary woody invaders on tobosa
(Hilaria mutica [Buckl.] grasslands and velvet mesquite (Prosopis juliflora [Swartz] DC) or honey mesquite (P. glandulosa Torr. var. glandulosa) are the main invaders on black grama (Bouteloua eriopoda Torr.) grasslands in New Mexico. On areas dominated by creosotebush in New Mexico, Beck and Tober (1985) found that exclusion of cattle or rabbits for 22 years did not have any consistent effect on herbaceous species. Likewise, removal of shrubs did not always result in an increase in herbaceous species. The conclusion was that "the concept that removal of these factors will result in range improvement was not consistently shown by the study".

On Rothrock grama (Bouteloua rothrockii Vasey) and black grama grasslands in southern Arizona, velvet mesquite density more than doubled from 1932 to 1949 on all grazing treatments as well as on areas protected from grazing (Glendening 1952). The increase was greatest on the protected plots. He concluded that "mesquite, once seed trees are present, may rapidly increase regardless of grazing treatment".

On degraded desert grasslands in Arizona, Smith and Schmutz (1975) reported that velvet mesquite continued to increase in areas protected from grazing from 1941 through 1969. Perennial grasses increased in cover and frequency during the period but the continuing increase of mesquite was considered to represent a threat to continued range improvement.

Changes of desert grasslands to shrublands in southern New Mexico have taken place during a period of change to a warmer, drier climate (Neilson 1986). In southern New Mexico, black grama seedlings were found in only 7 years between 1915 and 1968 during this warming period (Herbel et al. 1970). Heavy livestock grazing led to spatial and temporal heterogeneity of water, nitrogen, and other soil resources, which, in turn, led to the invasion of the desert shrubs that otherwise might have taken place over a much longer time because of "biological inertia" (Neilson 1986, Schlesinger et al. 1990).

Archer (1989) studied the history of conversion of mesquite savannas to woodlands in southern Texas and also concluded that the change has been recent and coincident with both heavy grazing by livestock and shifts in precipitation. He presented a conceptual diagram (Fig. 1) to attempt to explain the mechanisms of the

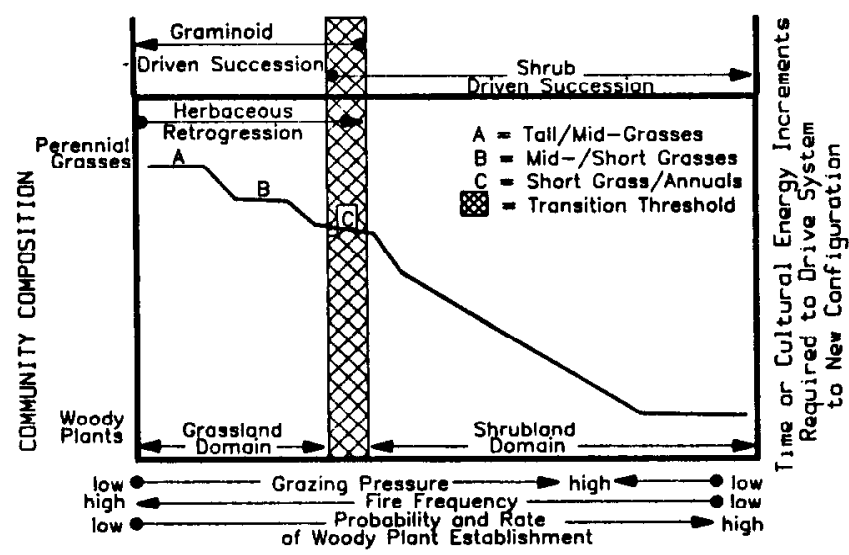

Fig. 1. Conceptual diagram of threshold changes in community structure from a grassland or savannah to a mesquite woodland as a function of grazing pressure. From Archer (1989). Copyright $\odot 1989$ by the University of Chicago. Reproduced by permission of the University of Chicago.

change. Graminoid driven succession predominates within the original grassland domain. Heavy grazing alters the composition and productivity of herbaceous species while decreasing fire frequency and intensity, thereby increasing the probability of woody- 
plant establishment. When sufficient numbers of woody plants become established, the community crosses a threshold (C-Fig. 1), shrub-driven successional processes begin to predominate and the site moves toward a new woodland steady-state configuration. Once in the woodland domain, the site does not revert to grassland even if grazing is stopped. Manipulations (fire, herbicides, root plowing, etc.) will temporarily alter the grass-shrub mixture, but subsequent shrub driven succession usually results in a rapid return of woody plants. The present condition of the rangeland is a steady state and this must be recognized for effective management to take place.

\section{Annual Grass Communities:}

There are 2 areas in the U.S. where perennial communities have been converted to annual grasslands. One is the California annual grassland which originally was a perennial bunch-grass dominated community (Biswell 1956). After settlement by the Spanish with their livestock in the late 18th century, and the accidental or intentional introduction of a number of well-adapted annuals from the Mediterranean and other regions of the world, the perennial vegetation was almost completely replaced by annual grass communities (Heady 1958). Only remnants of the original vegetation remain and there is little or no potential for the annual communities to return to their original condition. The annual communities represent recognizable, stable vegetation states with thresholds that are difficult to cross.

The other area dominated by annuals is in southern Idaho and surrounding areas. Cheatgrass brome (Bromus tectorum L.) and, in some areas, medusahead (Taeniatherum caput-medusae [L.] Nevski) now dominate more than 2.5 million hectares of former sagebrush-grass rangelands in southern Idaho and cheatgrass is an important species on another 8 million hectares (Murray et al. 1978). This condition was caused by cultivation and abandonment of land, heavy livestock grazing around the turn of the century, repeated fires which removed sagebrush plants and seed sources over large areas, and the presence of annuals highly adapted to the climate (Hull and Pechanec 1947). In areas where enough perennial herbaceous species remain, conservative grazing management may return the area to a perennial grassland over a long period of time. Large areas have few perennial grasses and no sagebrush close enough to provide seed for the return of the perennial species. In addition, because the cheatgrass is so flammable, fire-return frequency in cheatgrass-dominated areas is now less than 5 years in contrast to the pre-settlement frequency of 60-110 years (Whisenant 1990). These frequent fires do not allow perennial grasses, sagebrush, or other shrubs to establish and set seed.

Melgoza et al. (1990) determined that cheatgrass competes with native species for soil water and negatively affects their water status and productivity for at least 12 years after a fire. Allen (1988) discussed the possible combined effects of introduced weeds and mycorrhizae on slowing the rate and influencing the trajectory and end point of succession on areas dominated by annuals such as cheatgrass.

\section{Other Vegetation Types}

Jameson (1987) suggested the possibility of multiple stable states in pinyon-juniper woodlands. Baker (in press) found that, after a fire in a forest dominated by Englemann spruce (Picea englemani Parry) in the subalpine zone in Colorado, bristlecone pine (Pinus aristata Engelm.) became established on an area grazed by livestock. Englemann spruce has again become established on an adjacent ungrazed area inside a city watershed. The bristlecone pine is firmly established and probably would not be affected by removal of grazing, at least during the rather long lifetime of the existing trees.

\section{Implications of the Steady State/Threshold Model}

The range condition model currently used in the U.S. assumes that any rangeland area which is lower on the successional scale than "climax" can be moved toward a higher successional state by reducing or removing grazing (Laycock 1989, Westoby et al. 1989). This assumption often is incorrect; reduction or removal of grazing may have little effect on range condition in the intermediate or even long term for many ecosystems in relatively stable lower successional states. Using our present system, a fair or poor (mid to low-seral) range condition rating for these communities usually leads the manager to reduce grazing to improve range condition. For the stable states described previously, reduction or removal of grazing has little effect on range condition, thus invalidating our current concepts of range condition for these situations.

The present range condition concepts seem to work well in the more humid mixed grass and tall grass prairies of the Great Plains. No examples were found of lower successional steady states in these vegetation types and they may not exist under more humid conditions or they may be harder to recognize than in shrubland communities. However, invasion of juniper or other woody species into the tall grass prairie in the absence of grazing or fire could possibly eventually lead to lower successional states. In this case, removal of herbage by fire or grazing is the "normal" situation and removal of these factors represents a disturbance to the system.

A steady state/threshold concept can provide the framework for a new approach to understand how rangeland communities behave. We need to: (1) determine which vegetation types have relatively stable successional states; (2) develop criteria and methods to identify these states; (3) identify the thresholds which prevent the system from moving out of these states; (4) identify the fluctuations in composition which may occur in these stable states caused by weather or other factors; (5) develop a better understanding of what forces or perturbations, either natural or man-caused, cause a system to cross a threshold and move toward another state; and (6) adopt or develop conceptual models to organize and put this information into perspective. Connell and Sousa (1983) discussed the evidence needed to judge ecological stability but their criteria remain untested.

\section{Identification of Stable States and Thresholds}

Friedel $(1988,1991)$ examined data from extensive monitoring programs on Australian rangelands and used multivariate analysis and ordination to determine thresholds of environmental change and recognizable states or domains. She also analyzed trends in forage composition over time and found that composition on areas with poor grazing management fluctuated more than on wellmanaged areas, and that the 2 areas occupied different parts of the ordination space. These and similar techniques to identify similar plant communities are described in the literature and no further discussion will be presented here.

In addition to identifying stable states, conceptual models are needed to put them into perspective and organize information. One potentially useful concept depicts a community as a ball or marble in a cup or trough.

Lewontin (1969) presented mathematical models of stability and discussed the forces required to move an ecosystem out of a "basin of attraction" or stable state. Krebs (1985) elaborated on this model and Hurd and Wolf (1974) presented a "cup and ball" analogy to convey the concepts of stability and the force necessary to disturb that stability. Godron and Forman (1983) and Forman and Godron (1986) described a "Russian hills" model using troughs and a marble to describe stability of a physical system. The depth of the trough represents the range of environmental conditions under which that community is stable. A marble can be 
forced from one trough to another only by intense energy level or environmental change.

Figure 2-a represents a community that is both locally and globally stable (Lewontin 1969, Hurd and Wolf 1974 and Krebs 1985) because after all disturbances or perturbations, it will return to the original configuration. This model adequately represents the "climax" or "successional" range condition concept commonly used in the U.S., i.e., a given disturbed community will always return to the "climax" after the disturbance is stopped and no other steady state is possible. However, even in this "global" model, the

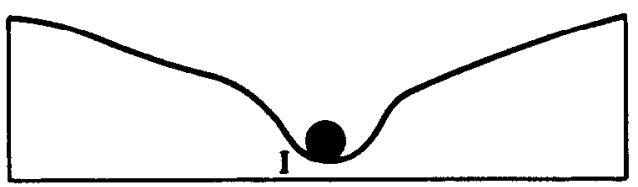

Range of environmental conditions

(a)

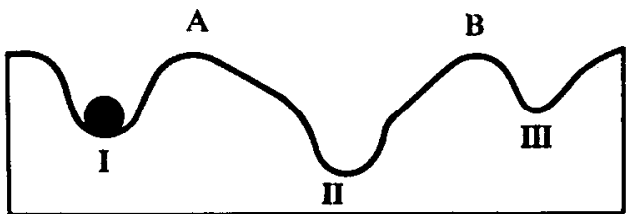

Range of environmental conditions

(b)

Fig. 2. Diagrams illustrating the ball and cup or trough analogy to illustrate global and local stabliity concepts. The community is represented as a black ball on a topographic surface (cup or trough) which represents the range of environmental conditions under which the community is stable. In (a) the community is both locally and globally stable because, after all disturbances or perturbations, it will return to configuration I. In (b) the community is locally stable, but if perturbed beyond a certain critical range, it will cross threshold $A$ and move to a new locally stable configuration II. From Ecology: The Experimental Analysis of Distribution and Abundance, Third Edition by Charles J. Krebs. Copyright $\theta$ 1985 by Harper and Row Publishers, Inc. Reproduced by permission of Harper Collins Publishers, Inc.

assumptions of linearity of change and the lack of hysteresis for pathways followed during retrogression and succession may not be valid.

Figure 2-b represents a community that has multiple stable points, only 3 of which are shown. It is locally stable at configuration I. If this configuration represents "excellent" rangeland condition, minor perturbations such as grazing may change the composition of the community but once these disturbances are lessened or stopped, the community returns to its original state (climax or excellent condition). While the community is within the bounds of configuration I, current concepts about range condition and reversibility of change may fit quite well. However, if the community is perturbed beyond a certain critical range, it will cross threshold A and move to a new locally stable configuration II. For a rangeland in this new stable state, conventional range condition concepts no longer apply either to describe the state or identify the forces required to move the community out of this state. If stressed beyond the limits of this new stable state, the community can then be forced across threshold B to configuration III or to some other possible configuration not shown. The depth of a trough represents the strength of the local stability or the energy or strength of disturbance required to force the community across a threshold and into another trough (stable state). For a given vegetation type, the troughs represent the numerous stable states that are possible at various stages of disturbance or recovery.

Lauenroth et al. (1978) used the "basin of attraction" concept to describe the response of shortgrass prairie vegetation to the stress of added nitrogen and water. Either water or nitrogen, when administered separately, induced some change in the vegetation composition, but both induced communities were still recognizable as a shortgrass type. When both water and nitrogen was added, biomass production was greatly stimulated and the conclusions were that "we judge its location (i.e., the community's) to be outside of the shortgrass basin (of attraction)."

Figure 3 is a diagram of the sagebrush-grass ecosystem described previously using the state-and-transition concept of Westoby et al. (1989). West $(1979,1988)$ diagrammed similar changes in sage-

\section{STATE-AND-TRANSITION MODEL FOR A SAGEBRUSH GRASS ECOSYSTEM \\ (After Westoby, Walker and Noy-Meir, 1989)}

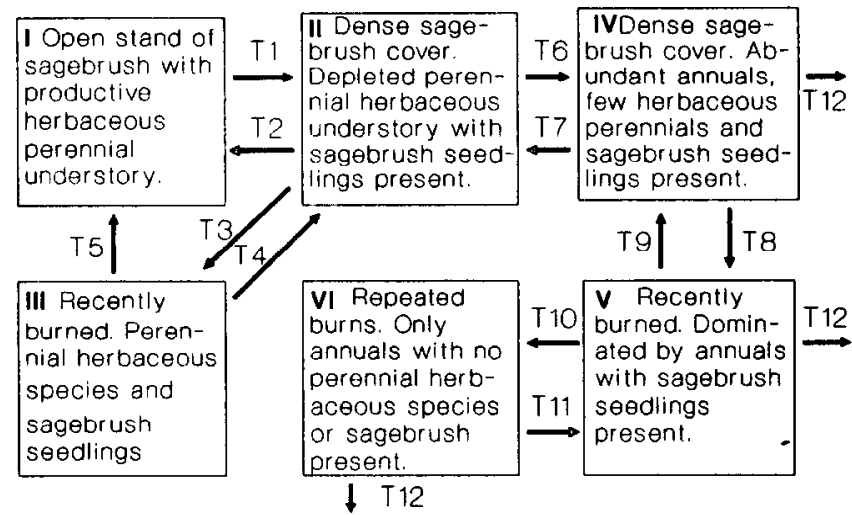

Fig. 3. State-and-transition diagram for sagebrush-grass vegetation.

Catalogue of Transitions

Transition 1-Heavy continued grazing. Rainfall conducive for sagebrush seedlings.

Transition 2-Difficult threshold to cross. Transitions usually will go through T3 and T5.

Transition 3-Fire kills sagebrush. Biological agents such as insects, disease or continued heavy browsing of the sagebrush by ungulates could have the same effect over a longer period of time. Perennial herbaceous species regain vigor.

Transition 4-Uncontrolled heavy grazing favors sagebrush and reduces perennial herbaceous vigor.

Transition 5-Light grazing allows herbaceous perennials to compete with sagebrush and to increase.

If climate is favorable for annuals such as cheatgrass, the following transitions may occur:

Transition 6-Continued heavy grazing favors annual grasses which replace perennials.

Transition 7-Difficult threshold to cross. Highly unlikely if annuals are adapted to area.

Transition 8-Burning removes adult sagebrush plants. Sagebrush in seed bank.

Transition 9-In absence of repeated fires, sagebrush seedlings mature and again dominate community.

Transition 10-Repeated burns kill sagebrush seedlings and remove seed source.

Transition 11-Difficult threshold to cross if large areas affected. Requires sagebrush seed source.

Transition 12-Intervention by man in form of seeding of adapted perennials.

brush vegetation. The boxes are stable states and the arrows represent transitions between states. States I, II, and III represent 3 recognizable stable states which may occur in areas without annuals. State II represents the degraded state resulting from prolonged heavy grazing, which remains dominated by sagebrush for long periods of time. Fire (transition 3), or some other force (insects, disease, rodents) that kills adult sagebrush plants, will release the perennial understory from competition. Heavy consumption of the sagebrush by a browsing animal might achieve the same effect over 
a longer period of time. State IV represents a situation that might occur in heavily grazed areas where a well-adapted annual, such as cheatgrass, replaces the native perennial species in the understory. Fire (transition 8) and repeated fire (transition 10) can then convert this community into a stable state dominated by annuals (state VI). Fire-return frequencies in cheatgrass-dominated areas may be less than 5 years (Whisenant 1990). Transition 12 represents intervention by man in the form of seeding to adapted perennial species such as crested wheatgrass (Agropyron desertorum [Fisch.] Schult and A. cristatum L. Gaerth.). The Bureau of Land Management is experimenting with crested wheatgrass and other grasses, forbs and shrubs to provide less flammable vegetative fuelbreaks in extensive cheatgrass areas in southern Idaho (Pellant 1990).

One possible erroneous impression conveyed by the state-andtransition diagram is that the double transition arrows between adjacent states may imply that the various stable states which occur during improvement or succession are the same as those that occurred in retrogression. This is one major shortcoming of the curent "succession" range condition model. The narrative by Westoby et al. (1989) makes it clear that this implication is not intended. Instead, the boxes or states in the diagram include only a few of the possible states and thus represent the same concept as the cups or troughs shown in Figure 2-b in the previous example. To use either model, the number of possible steady states and the strengths of the stability of each state need to be identified for both deteriorating and improving situations on each vegetation type or range site.

\section{Factors Which Cause an Ecosystem to Cross a Threshold}

In order to develop new concepts and models about range condition, we not only need to identify possible stable states, we also need to identify and understand the factors which can force a stable community across a threshold into a transitional phase moving toward another stable state. Tueller (1973) discussed many such disturbance factors for shrub-dominated ecosystems. Some drastic events are effective in short-term ( 1 year or less): floods, plowing, seeding of perennials, and selective plant control. A major change in fire frequency may be one of the factors preventing a community from re-crossing a threshold. The cheatgrass communities discussed previously are a good example of increased fire frequency maintaining a stable state. Most other factors, including selective grazing or lack of grazing, operate only if continued for a much longer period. Most of the stable state communities in North America appear to involve either a change in fire frequency or introduction of an alien species in addition to other factors such a grazing.

\section{Conclusions}

Multiple stable states do appear to be present for many arid and semi-arid rangeland vegetation types. The examples presented were not subjected to the criteria Connell and Sousa (1983) indicated to be needed to judge stability but their criteria may not be appropriate. Also, steady state concept on rangelands may only be pertinent in a time frame which is meaningful to management, usually up to several decades but somewhat longer in some situations. In a longer time frame (centuries or millennia), climatic changes or cycles or other changes may make the concept somewhat meaningless. However, it is the need for changes in management concepts that have prompted the search for new concepts and models.

While much theoretical work needs to be done before most of the models presented can be incorporated into range condition standards, it is important for managers to recognize that multiple steady states do exist on many rangelands. For example, many allotment management plans on sagebrush-grass rangelands have something similar to the following as an objective: Change the condition of the site from fair (mid-seral) to good (upper seral) in 2 (or 3 ) cycles of a grazing system. The reason for the low range condition almost always is too much sagebrush and, usually, the only way to improve range condition is to reduce the amount of sagebrush. On ranges grazed only by cattle, no known cattle grazing system will accomplish that. The most practical way to reduce the sagebrush and increase range condition is to burn, spray, or otherwise kill all or part of the sagebrush in conjunction with proper grazing management. However, on deer winter ranges, fairly dramatic reductions in sagebrush can occur over a number of years because of heavy browsing of the sagebrush by deer (Urness 1990). Under some conditions, spring deferment and heavy fall or winter grazing by sheep can also achieve some reductions in amount of sagebrush (Laycock 1967, Frischknecht and Harris 1973).

Similar examples could be cited for other range vegetation types. If the manager does not recognize that multiple stable states exist, he/she generally assumes that a change in grazing management (stocking rate, system, etc.) is all that is required to achieve an improvement in range condition. If the current stable state of the vegetation is highly resistant to changes due to grazing management, both the manager and the livestock owner have been misled by our current concepts and they will be disappointed by the lack of response. This is why it is highly important that a dialogue be started among scientists and managers alike concerning multiple stable states and thresholds.

\section{Literature Cited}

Allen, E.B. 1988. Some trajectories of succession in Wyoming sagebrush grassland: implications for restoration. p. 89-112 In: E.B. Allen(ed). The reconstruction of disturbed arid lands: an ecological approach. Westview Press, Boulder, Colo.

Anderson, J.E., and K.E. Holt. 1981. Vegetation development over 25 years without grazing on sagebrush dominated rangeland in southeastern Idaho. J. Range Manage. 34:25-29.

Archer, S. 1989. Have southern Texas savannas been converted to woodlands in recent history? Amer. Natur. 134:545-561.

Baker, W.L. In Press. Livestock grazing alters succession after fire in a Colorado subalpine forest. p. In: $\mathrm{S}$. Nodvin and T. Waldrop (eds). Proc. Fire and the Environment Symp. (Knoxville, Tenn, Mar. 20-24, 1990). USDA Forest Serv./ USDI Nat. Park Serv.

Beck, R.F., and D.A. Tober. 1985. Vegetational changes on creosotebush sites after removal of shrubs, cattle and rabbits. New Mexico State Univ., Agr. Exp. Sta. Bull. 717.

Biswell, H.H. 1956. Ecology of California grasslands. J. Range Manage. 9:19-24.

Clements, F.E. 1916. Plant succession. Carnegie Inst. Wash. Pub. 242.

Coffin, D.P., W.K. Lauenroth, and I.C. Burke. 1991. Recovery of shortgrass steppe plant communities in northeastern Colorado. Abstracts of Papers. No. 82, 44th Annual Meeting, Society for Range Management, Washington, D.C.

Connell, J.H., and W.P. Sousa. 1983. On the evidence needed to judge ecological stability or persistence. Amer. Natur. 121:789-824.

Costello, D.F., and G.T. Turner. 1944. Judging condition and utilization of short-grass ranges on the central Great Plains. USDA Farmers Bull. 1949.

Costello, D.F. 1944. Natural revegetation of abandoned plowed land in the mixed prairie association of northeastern Colorado. Ecol. 25:312-326.

Dyksterhuis, E.J. 1949. Condition and management of rangeland based on quantitative ecology. J. Range Manage. 2:104-115.

Egler, F.E. 1954. Vegetation science concepts: 1 . initial floristic composition, a factor in old-field vegetation development. Vegetatio 4:412-417.

Ellison, L. 1960. Influence of grazing on plant succession of rangelands. Bot. Rev. 26:1-78.

Foran, B.D., N.M. Tainton, P. de Va. Booysen. 1978. The development of a method for assessing veld condition in three grassland types in Natal. Proc. Grassl. Soc. So. Africa 13:27-33.

Forman, R.T.T., and M. Godron. 1986. Landscape ecology. John Wiley \& Sons, New York.

Friedel, M.H. 1988. Range condition and the concept of thresholds. p. 1-3. In: Vol. I, Abstracts, 3rd Intern. Rangeland Congr. Range Manage. Soc. India. 
Friedel, M.H. 1991. Range condition assessment and the concept of thresholds. A Viewpoint. J. Range Manage. 44:422-426.

Frischknecht, N.C., and L.E. Harris. 1973. Sheep can control sagebrush on seeded range if... Utah Sci. 34:27-30.

Gleason, H.S. 1926. The individualistic concept of plant association. Bull. Torrey Bot. Club. 53:7-26.

Glendening, G.E. 1952. Some quantitative data on the increase of mesquite and cactus on a desert range in southern Arizona. Ecol. 33:319-328.

Godron, M., and R.T.T. Forman. 1983. Landscape modification and changing ecological characteristics. p. 12-18. In: H.A. Mooney and M. Godron (eds). Disturbance and ecosystems: components of response. Springer-Verlag, New York.

Hart, R.H., and B.E. Norton. 1988. Grazing management and vegetation response. p. 494-525. In: P.T. Tueller (ed). Vegetation science applications for rangeland analysis and management. Kluwer Academic Publ., Boston, Mass.

Herbel, C.H..., P.L. Dittberner, and T.S. Bickle. 1970. A quantitative ecology of the Jornada Experimental Range. p.I-133-I-178. In: R.G. Wright and G.M. Van Dyne (eds). Colorado State Univ. Range Sci. Dept. Rep. 6. Ft. Collins.

Heady, H.F. 1958. Vegetation changes in the California annual type. Ecology 39:402-415.

Holling, C.S. 1973. Resilience and stability of ecological systems. Annu. Rev. Ecol. Systematics 4:1-23.

Hull, A.C., Jr., and J.F. Pechanec. 1947. Cheatgrass-a challenge to range research. J. Forest. 45:555-564.

Hurd, L.E., and L.L. Wolf. 1974. Stability in relation to nutrient enrichment in arthropod consumers of old-field successional ecosystems. Ecol. Monogr. 44:465-482.

Jameson, D.A. 1987. Climax or alternative steady states in woodland ecology. p. 9-13. In: Everett, R.L., compiler. Proc. Pinyon-juniper conference (Reno, Nev., Jan. 13-16, 1986). USDA, Forest Serv., Gen. Tech. Rep. INT-215, Intermount. Res. Sta., Ogden, Utah.

Krebs, C.J. 1985. Ecology: The experimental analysis of distribution and abundance. 3rd Ed. Harper and Row, New York.

Lauenroth, W.K., J.L. Dodd, and P.L.Sims. 1978. The effects of water and nitrogen-induced stresses on plant community structure in a semiarid grassland. Oecologia 36:211-222.

Laycock, W.A. 1967. How heavy grazing and protection affect sagebrush grass range. J. Range Manage. 20:206-213.

Laycock, W.A. 1978. Factors affecting choice of management strategies within the sagebrush ecosystem. p. 230-236. In: The sagebrush ecosystem: A symposium. College of Natur. Resour., Utah State Univ., Logan.

Laycock, W.A. 1989. Secondary succession and range condition criteria: Introduction to the problem. p. 1-15. In: W.K. Lauenroth and W.A. Laycock, (eds). Secondary succession and the evaluation of rangeland condition. Westview Press, Boulder, Colo.

Lewontin, R.C. 1969. The meaning of stability. p. 13-24. In: Diversity and stability in ecological systems. Brookhaven Symp. in Biology 22. Springfield, Va.

Margalef, R. 1969. On certain unifying principles in ecology. Amer. Natur. 97:357-374.

May, R.M. 1977. Thresholds and breakpoints in ecosystems with a multiplicity of stable states. Nature 269:471-477.

Melgoza, G., R.S. Nowak, and R.J. Tausch. 1990. Soil water exploitation after fire: Competition between Bromus tectorum (cheatgrass) and two native species. Oecologia 83:7-13.

Murray, R.B., H.F. Mayland, and P.J. Van Soest. 1978. Growth and nutritional value to cattle of grasses on cheatgrass range in southern Idaho. USDA Forest Serv. Res. Pap. INT-199, Intermt. Forest and Range Exp. Sta., Ogden, Utah.

Neilsen, R.P. 1986. High-resolution climatic analysis and southwestern biogeography. Science 232:27-34.

Norton, B.E. 1978. The impact of sheep grazing on long-term successional trends in salt desert shrub vegetation of southwestern Utah. p. 610-612. In: D.N. Hyder (ed). Proc. First Internat. Range Cong., Soc. Range Manage., Denver, Colo.

Paulsen, H.A. Jr., and F.N. Ares. 1962. Grazing values and management of black grama and tobosa grasslands and associated shrub ranges of the Southwest. USDA, For. Serv. Tech. Bull. 1270.

Pellant, M. 1990. The cheatgrass-wildfire cycle-are there any solutions? $p$. 11-18. In: E.D. McArthur, E.M. Romney, S.D. Smith and P.T. Tueller (eds). Proceedings - a symposium on cheatgrass invasion, shrub die-off, and other aspects of shrub biology and management. U.S. Forest. Serv. Gen. Tech. Rep. INT-276. Intermountain Res. Sta., Ogden, Utah.

Rice, B., and M. Westoby. 1978. Vegetative responses of some Great Basin shrub communities protected against jackrabbits or domestic stock. J. Range Manage. 31:28-34.

Robertson, J.H. 1971. Changes on a grass-shrub range in Nevada ungrazed for 30 years. J. Range Manage. 24:397-400.

Sampson, A.W. 1919. Plant succession in relation to range management. USDA Bull. 791 amuel, M.J, 1985. Growth parameter differences between populations of blue grama. J. Range Manage. 38:339-342.

Samuel, M.J., and R.H. Hart. 1990. Sixty years of successon on the Wyoming High Plains. No. 217. Abstr. of papers, 43rd Annu. Meeting, Soc. Range Manage., Reno, Nev.

Sanders, K.D., and A.A. Voth. 1983. Ecological changes of grazed and ungrazed plant communities. p. 176-179. In: Managing Intermountain rangelands-improvement of range and wildlife habitats. USDA, Forest Serv. Gen. Tech. Rep. INT-157.

Sandor, J.A. 1983. Soils at prehistoric agricultural terracing sites in New Mexico. PhD Diss., Univ. California, Berkeley.

Schlatterer, E.F. 1989. Toward a user-friendly ecosystem: myth or mirth? p. 223-227. In: D.E. Ferguson, P. Morgan, and F.D. Johnson (eds). Proc.: Land Classifications Based on Vegetation: Applications for Resource Management. USDA Forest Serv. Gen. Tech. Rep. INT-257, Intermt. Forest and Range Exp. Sta., Ogden, Utah.

Schlesinger, W.G., J.F. Reynolds, G.L. Cunningham, L.F. Huenneke, W.W. Jarrell, R.A. Virginia, and W.G. Whitford. 1990. Biological feedbacks in global desertification. Science 247:1043-1048.

Sharp, L.A., K. Sanders, and N. Rimbey. 1990. Forty years of change in a shadscale stand in Idaho. Rangelands 12:313-328.

Smith, D.A., and E.M. Schmutz. 1975. Vegetative changes on protected versus grazed desert grassland ranges in Arizona. J. Range Manage. 28:453-458

Smith, E.L. 1978. A critical evaluation of the range condition concept. $p$. 226-267. In: D.N. Hyder (ed). Proc. First Internat. Rangel. Congr., Soc. Range Manage., Denver, Colo.

Smith, E.L. 1988. Successional concepts in relation to range condition assessment. p. 113-133. In: P. Tueller (ed). Vegetation science applications for rangeland analysis and management. Dr. W. Junk. The Hague.

Smith, E.L. 1989. Range condition and secondary succession: a critique. p. 103-141. In: W.K. Lauenroth and W.A. Laycock (eds). Secondary succession and the evaluation of rangeland condition. Westview Press, Boulder, Colo.

Tueller, P.T. 1973. Secondary succession, disclimax, and range condition standards in desert shrub vegetation. p. 57-65. In: D.N. Hyder (ed). Arid shrublands. Soc. Range Manage., Denver, Colo.

Turner, G.T. 1971. Soil and grazing influences on a salt-desert shrub range in western Colorado. J. Range Manage. 24:31-37.

Urness, P.J. 1990. Livestock as manipulators of mule deer winter habitats in northern Utah. p. 25-40. In: K.E. Severson (ed). Can livestock be used as a tool to enhance wildlife habitat? U.S. Forest Service Gen. Tech. Rep. RM-194. Rocky Mountain Forest and Range Experiment Station, Ft. Collins, Colo.

Verhoff, F.H., and F.E. Smith. 1971. Theoretical analysis of a conserved nutrient ecosystem. J. Theor. Biol. 33:131-147.

West, N.E. 1979. Basic synecological relationship of sagebrush-dominated lands in the Great Basin and Colorado Plateau. p. 33-41. In: The sagebrush ecosystem: A symposium. College of Natur. Resour., Utah State Univ., Logan.

West, N.E. 1988. Intermountain deserts, shrub steppes, and woodlands. p. 210-230. In: M.G. Barbour and W.D. Billings (eds). North Amer. Terrestrial Vegetation. Cambridge Univ. Press, New York.

West, N.E., F.D. Provenza, P.S. Johnson, and M.K. Owens. 1984. Vegetation change after 13 years of livestock grazing exclusion on sagebrush semidesert in central Utah. J. Range Manage. 37:262-264.

Westoby, M., B. Walker, and I. Noy-Meir. 1989. Opportunistic management tor rangelands not at equilibrium. J. Kange Manage. 42:266-274.

Whisenant, S.G. 1990. Changing fire frequencies on Idaho's Snake River Plains: ecological and management implications. p. 4-10. In: E.D. McArthur, E.M. Romney, S.D. Smith and P.T. Tueller (eds). Proceedings - a symposium on cheatgrass invasion, shrub die-off, and other aspects of shrub biology and management. U.S. Forest Serv. Gen. Tech. Rep. INT-276. Intermountain Research Station, Ogden, Utah.

Wissel, C. 1984. A universal law of the characteristic return time near thresholds. Oecologia 65:101-107.

Wilson, A.M., and D.D. Briske. 1979. Seminal and adventitious root growth of blue grama seedlings on the Central Plains. J. Range Manage. 32:209-213.

Wilson, A.D. 1989. The development of systems of assessing the condition of rangeland in Australia. p. 77-102. In: W.K. Lauenroth and W.A. Laycock (eds). Secondary succession and the evaluation of rangeland condition. Westview Press Boulder, Colo.

Young, J.A., R.E. Eckert, and R.A. Evans. 1979. Historical perspectives regarding the sagebrush ecosystem. p. 1-13. In: The sagebrush ecosystemA symposium. Utah State Univ., Logan.

Young, J.A., R.A. Evans, and P.T. Tueller. 1976. Great Basin plant communities-pristine and grazed. p. 187-215. In: R. Elson (ed). Holocene environmental change in the Great Basin. Nevada Archaeological Survey Research Paper 6. Reno, Nev. 